\title{
THE EFFECTS OF ACTH, ISOPROTERENOL AND DEXAMETHASONE ON THE RAT ADRENAL GLAND RESPONSE TO ETHANE DIMETHANESULPHONATE (EDS): A STEREOLOGICAL STUDY
}

PLEĆAŠ-SOLAROVIĆ BOSILJKA*, PEŠIĆ VESNA*, MIRKOVIĆ D** and LEPOSAVIĆ GORDANA*

*Department of Physiology, Faculty of Pharmacy, University of Belgrade

${ }^{\star *}$ Institute of Biochemistry, Clinical Centre of Serbia, Belgrade

\section{(Received 12 June 2003)}

Ethane dimethanesulphonate (EDS), an alkylating agent, caused marked atrophy of the adrenal cortex of adult male rats, in addition to its toxic effect on testicular Leydig cells. The aim of this work was to examine whether a 9-day treatment with ACTH (40 IU/ $\mathrm{kg} / \mathrm{d})$, isoproterenol $(120 \mu \mathrm{g} / \mathrm{kg} / \mathrm{d})$ or dexamethasone $(0.25 \mathrm{mg} / \mathrm{kg} / \mathrm{d})$, which started 4 days prior to intraperitoneal administration of a single dose of EDS (75 $\mathrm{mg} / \mathrm{kg}$ ), affected the morphological changes in the adrenal cortex evoked by EDS alone. The animals were killed 15 days after EDS injection. Stereological analysis revealed that both ACTH and isoproterenol almost completely prevented cortical atrophy induced by EDS. They also considerably stimulated corticosterone secretion in EDS-injected animals. By contrast, in dexamethasone-suppressed rats, the deleterious effect of EDS on adrenocortical cells was augmented. The volume and cellularity of all cortical zones were reduced, but the remaining cells of the zona reticularis displayed considerable hypertrophy, which was probably responsible for the maintenance of corticosterone secretion. These results clearly demonstrate that both ACTH and $\beta$ adrenoceptor stimulation have protective action against the toxic effects of EDS on rat adrenal cortex, whereas dexamethasone exerts an opposite influence.

Key words: Ethane dimethanesulphonate, rat adrenal cortex, $\mathrm{ACTH}$, isoproterenol, dexamethasone, stereology, corticosterone.

\section{INTRODUCTION}

The methane sulphonates are alkylating agents, which have been developed for chemotherapy and are often used in examining genotoxicity (Shealy and Krauth, 1993; Ehling and Neuhäuser-Klaus, 1995). Originally, ethane 1,2-dimethane sulphonate (EDS) was considered to destroy Leydig cells specifically in the testis of adult rats and some other rodents, leading to very low levels of testosterone in the blood and transient infertility (Jackson and Jackson, 1984; Klinefelter et al., 1991). However, increasing data indicate that EDS may have more extended effects that are independent of the elimination of Leydig cells. Thus, the agent has 
been shown to influence directly the rat epididymal epithelium (Klinefelter et al., 1992), the seminiferous epithelium (Sprando et al., 1990), adenohypophysial gonadotropes (Dong and Handelsman, 1991) and thymocytes (Morris et al., 1997). We have previously reported that EDS has a strong deleterious effect on steroidogenic cells of adult male rat adrenal cortex (Plećaš et al., 1997), which was manifested by marked atrophy of the inner cortical zone 15 days after administration of EDS. Our further investigation showed that the secretory response of adrenocortical cells to EDS can be modified in an opposite fashion with ACTH and dexamethasone (Plećaš et al., 2001).

The aim of this work was to examine the morphometric characteristics of rat adrenal glands that, at the time of EDS application, were stimulated by exogenous ACTH or suppressed by dexamethasone. Besides that, since we have reported that chronic administration of $\beta$-adrenergic receptor agonist or antagonist might influence the structure (Plećaš et al., 1996) and function (Plećaš et al., 1999) of the adrenal cortex, the effects of EDS were also examined in animals treated with the $\beta$-adrenergic receptor agonist isoproterenol.

\section{MATERIAL AND METHODS}

Adult male Wistar rats, weighing $250-300 \mathrm{~g}$ at the beginning of the experiment, were housed under conditions of controlled temperature $\left(19-21^{\circ} \mathrm{C}\right)$ and light (12 $\mathrm{h}$ darkness $/ 12 \mathrm{~h}$ light) with constant access to a standard diet and tap water. They were divided into groups $(n=7$ each) that were injected subcutaneously with saline $(1 \mathrm{ml} / \mathrm{kg} / \mathrm{d})$, ACTH (40 lU/kg/d; ACTH, ICN-Galenika), isoproterenol $(120 \mu \mathrm{g} / \mathrm{kg} / \mathrm{d}$; Isoproterenol hydrochloride, SIGMA) or dexamethasone $(0.25$ $\mathrm{mg} / \mathrm{kg} / \mathrm{d}$; Dexamethasone, ICN-Galenika) for 9 consecutive days. On day 4 of the treatment, all the animals received a single intraperitoneal injection of EDS (75 $\mathrm{mg} / \mathrm{kg}$ ). An additional control group was injected with saline for 9 days, but on the $4^{\text {th }}$ day received intraperitoneally the vehicle for EDS, dimethylsulphoxide (DMSO) in water $(3: 1 \mathrm{v} / \mathrm{v})$. Since EDS is not commercially available, it was synthesised in our laboratory by the procedure described by Jackson and Jackson (1984). The rats were killed 15 days following EDS or DMSO administration.

To avoid corticosterone fluctuations due to the circadian rhythm, all experiments were performed between 9-11 h. The animals were handled gently and all efforts to minimise stress were made.

At the time of killing, rats were anaesthetised with ether and blood samples were taken by cardiac puncture within 2 min of total anaesthesia (Villas et al., 1991). After decapitation, the adrenal glands were dissected out and individually weighed.

\section{Morphometric analysis}

The left adrenal gland was fixed in Bouinžs fluid, dehydrated in a graded series of alcohols and embedded in paraffin. Serially cut sections, $6 \mu \mathrm{m}$ thick, were stained with hematoxylin and eosin.

Stereological measurements were carried out by a procedure similar to that described by Malendowicz (1997) as reported earlier (Plećaš et al., 1990). 
Acta Veterinaria (Beograd), Vol. 53. No. 5-6, 333-342, 2003.

Plećaš-Solarović Bosiljka et al. The effects of ACTH, isoproterenol and dexamethasone on

the rat adrenal gland response to ethane dimethanesulphonate (EDS): a stereological study

Level I: Zonation of the adrenal gland. In order to evaluate the volumetric densities of individual adrenocortical zones (zona glomerulosa, ZG; zona fasciculata, ZF; zona reticularis, ZR) and of the adrenal medulla, every sixth section of the gland was measured by a point counting method at a $125 \mathrm{x}$ magnification and with a square-lattice test system of type $A$ (Weibel, 1979). The volume of the fixed gland was also determined stereologically, by counting the number of points falling on the gland on every sixth section.

Level II: Size and number of adrenocortical cells. One or two equatorial sections of each gland were chosen and 30 test areas of $Z G$ and 50 test areas of ZF and of ZR were estimated at a $1000 \times$ magnification with the multipurpose test system $\mathrm{M}_{42}$ (Weibel, 1979). From the volume fractions of nuclei and cytoplasm, as well as the number of nuclear profiles of parenchymal cortical cells, the average volume of adrenocortical cells and their nuclei and the number of adrenocortical cells in each zone were calculated.

\section{Biochemical determinations}

The right adrenal gland was immediately frozen and kept at $-70^{\circ} \mathrm{C}$ until corticosterone determination by high performance liquid chromatography (HPLC). Adrenal corticosterone levels were expressed as ng per mg of adrenal tissue.

After separation, the serum was frozen and stored at $-20^{\circ} \mathrm{C}$ until assayed. Serum levels of corticosterone were estimated by RIA with a commercially available kit for rats $\left(\left[{ }^{125}\right]\right]$ corticosterone radioimmunoassay, ICN Biomedicals, CA).

\section{Statistics}

The results are presented as means \pm SEM. Statistical analysis was carried out using one-way analysis of variance (ANOVA) followed by the least significant difference test (LSD). $p<0.05$ was considered statistically significant.

\section{RESULTS}

The results are shown in Table 1 and Figure 1.

Fifteen days following the administration of a single dose of EDS to salineinjected rats marked changes were found in the stereological parameters of the adrenal gland comparing to the values obtained in saline and DMSO-injected controls. Significant reductions were observed in the volumes of the gland, cortical zones and the medulla. EDS reduced the number of parenchymal cells in all three cortical zones. In the ZG and ZF the mean cell volume was decreased, whereas the mean nuclear volume was decreased in the ZF and ZR. Despite these prominent morphological changes in the gland, adrenal and serum corticosterone concentrations were not significantly altered.

In the rats which on the $4^{\text {th }}$ day of the 9-day ACTH treatment received EDS, adrenal volume was greater than in animals injected with saline and EDS and was similar to the value found in saline and DMSO-injected controls. The volumes of the ZG and ZF were increased. In the ZG only the cell volume was increased, whereas in the ZF enhancements were found both in the cellular and nuclear volumes. The mean cellular volume was increased in the ZR, as well. Corticosterone 


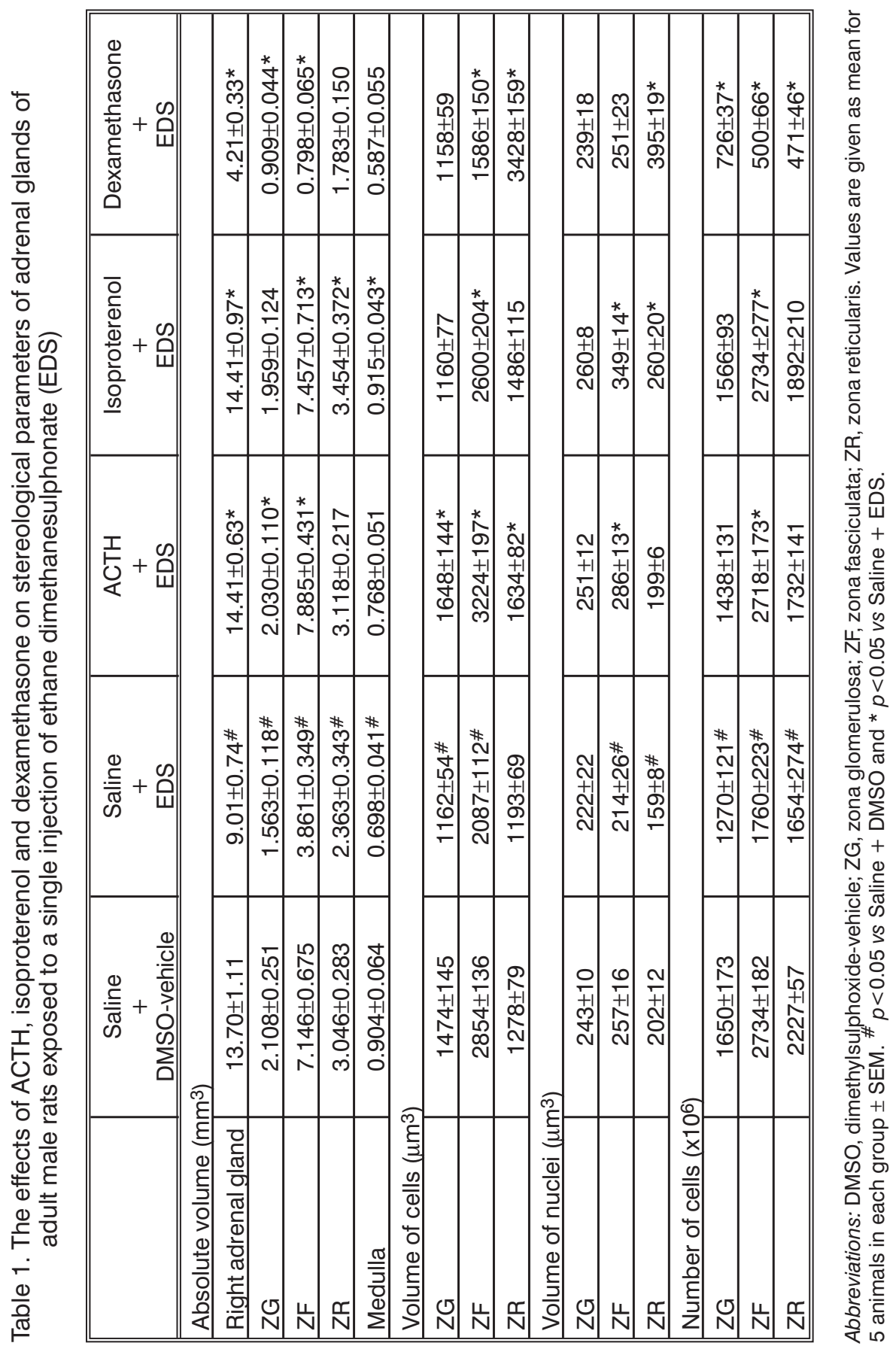


Acta Veterinaria (Beograd), Vol. 53. No. 5-6, 333-342, 2003.

Plećaš-Solarović Bosiljka et al. The effects of ACTH, isoproterenol and dexamethasone on the rat adrenal gland response to ethane dimethanesulphonate (EDS): a stereological study

concentration was significantly elevated in the serum, but not in the adrenals of these animals.

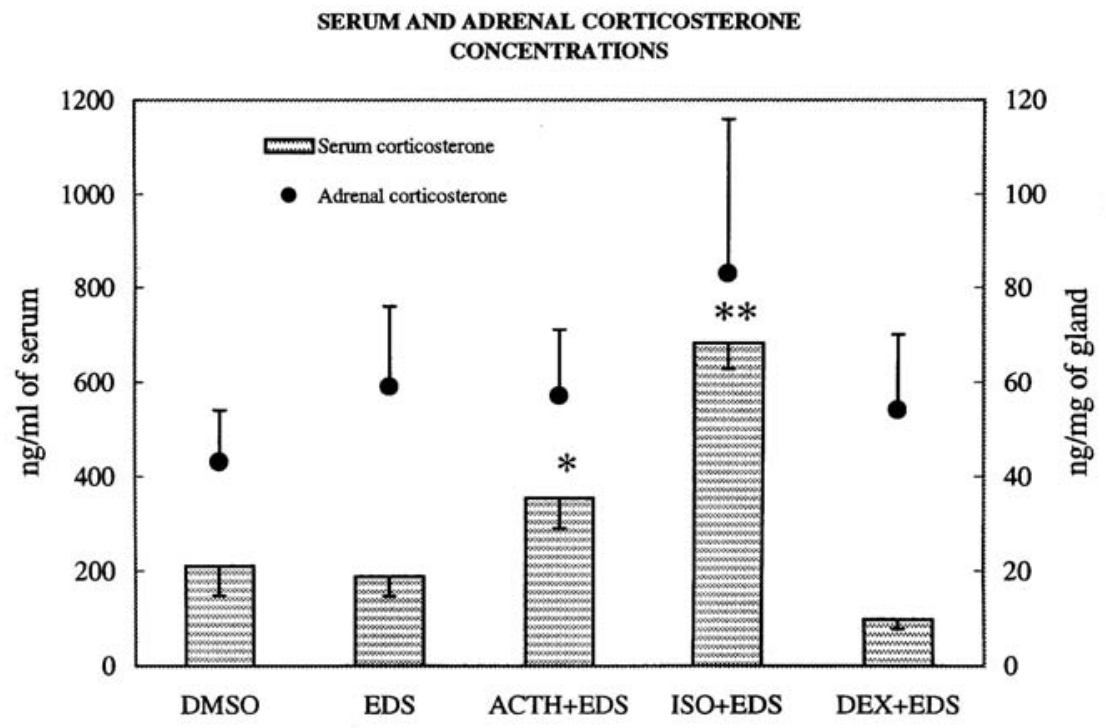

Figure 1. Serum (bars) and adrenal (dots) corticosterone concentrations in rats injected with saline and DMSO-vehicle, saline and EDS, and combinations of ACTH, isoproterenol (ISO) or dexamethasone (DEX) with EDS. Results are expressed as means \pm SEM. The final number of corticosterone samples was 5-7 in the group. ${ }^{*} p<0.05$ and ${ }^{* *} p<0.01$ vs the EDS-injected rats

Treatment with ISO and EDS enhanced the volume of the whole gland, ZF, ZR and the medulla. In the ZF increases were recorded in the cell and nuclear volume and the total cell number, whereas in the ZR only the mean nuclear volume was enlarged. In comparison with the values measured in rats injected with saline and EDS, serum corticosterone concentrations were almost 4 times higher. Adrenal corticosterone concentrations, however, were not significantly altered.

In the rats that received dexamethasone and EDS, significant decreases were found in the adrenal volume and the volumes of the ZG and ZF compared to saline and EDS-injected controls. In the ZG the total number of cells was decreased, whereas in the ZF both the cell volume and the total number of cells were decreased. However, in the ZR cellular and nuclear volumes were greatly enhanced, while the total cell number was reduced. No change in the adrenal corticosterone concentrations was detected, and the almost $50 \%$ decrease in serum corticosterone concentration was not statistically significant. 


\section{DISCUSSION}

The results of this work demonstrate that the toxic effects of EDS on the rat adrenal cortex can be modified by treatments known to affect the hypothalamopituitary-adrenal axis, i.e. by $\mathrm{ACTH}$, dexamethasone or isoproterenol, the $\beta$-adrenoceptor agonist.

As was shown earlier (Plećaš et al. 1997), adrenal gland weight is markedly decreased on day 15 after administration of a single dose of EDS and atrophic changes, measured stereologically, were most prominent in the ZF and ZR. However, the regressive changes in the gland were not accompanied by alterations in glandular and serum corticosterone levels. Several explanations for this discrepancy are possible. Firstly, the adrenal cortex has a tremendous functional reserve (Ribelin, 1984) and the magnitude of cortical atrophy evoked by EDS might be insufficient to be reflected by corticosterone levels. On the other hand, during the 15-day period after EDS administration the regenerative process might already have started, since adrenal weight is fully restored 30 days following injection (Plećaš et al. 2001). In almost all biological systems affected by EDS the nature of the changes has been found to be transitory; for instance, thymic weight recovers by 7 days after injection of EDS (Leeming et al., 1991). A compensatory stimulation of the inner zone might also occur. In favor of this latter assumption is the marked hypertrophy of a number of parenchymal cells in the ZR of EDS-injected rats observed in this and previous work (Plećaš et al. 1997).

Administration of ACTH or isoproterenol 4 days before and 5 days after EDS almost completely prevented adrenocortical regression.

Compared with EDS-injected animals, in rats injected with both ACTH and EDS, significant increases were found in the glandular and ZF and ZR volumes, the mean cellular volume in all cortical zones, as well as in the volume of nuclei and the total number of parenchymal cells in the ZF. Stereological parameters were similar to those in DMSO-injected controls except for the ZR cell volume, which was significantly greater $(28 \%, p<0.05)$. The protective effect of ACTH against the toxic influence of EDS on the adrenal cortex is analogous to the action of human chorionic gonadotrophin on rat Leydig cells in the presence of EDS (Jackson and Jackson, 1984). The considerably elevated serum corticosterone level in these animals indicates that parenchymal cells preserve their functional capacity and respond to ACTH by corticosterone secretion. Whether the action of ACTH on adrenocortical cells exposed to EDS is direct or via endogenous glucocorticoids, as has been shown for testosterone and Leydig cells (Jackson and Jackson, 1984), remains to be established. Yet, it has to be pointed out that the synthetic glucocorticoid, dexamethasone, augmented the harmful effects of EDS on adrenocortical structure.

Isoproterenol, administered according to the same experimental protocol, had similar effects as ACTH, particularly on the ZF. All morphometrical parameters measured in this zone, as well as the serum corticosterone concentration, were significantly greater than in rats injected with saline and EDS. These results confirm our previous findings that a longer, 15-day, treatment with isoproterenol markedly stimulated corticosterone secretion both in intact and EDS-injected rats 
Acta Veterinaria (Beograd), Vol. 53. No. 5-6, 333-342, 2003.

Plećaš-Solarović Bosiljka et al. The effects of ACTH, isoproterenol and dexamethasone on

the rat adrenal gland response to ethane dimethanesulphonate (EDS): a stereological study

(Plećaš et al., 1999). The site(s) of isoproterenol action is difficult to ascertain since $\beta$ adrenoceptors are present in all components of the hypothalamo-pituitary-adrenal axis (Tilders et al., 1982; Shima et al., 1984; Sato et al., 1989; Nussdorfer, 1996; Ehrhart-Bornstein et al., 1998). Systemic administration of isoproterenol was shown to stimulate both $\mathrm{ACTH}$ and corticosterone secretion in the rat (Berkenbosch et al., 1981; Tilders et al., 1982), although this substance does not cross the blood-brain-barrier (Carlisle et al., 1999). Besides that, $\beta$ adrenoceptor activation can influence the production of cytokines, particularly IL-6, by cortical macrophages (Maisel et al., 1989) or adrenal cells themselves (Judd et al., 1990; Judd and MacLeod, 1995). IL-6 alone and in synergism with ACTH stimulates the release of corticosterone from rat adrenocortical cells (Salas et al., 1990).

Isoproterenol, unlike ACTH, did not influence the morphometric characteristics of the ZG of rats injected with EDS. It is well documented that catecholamines, acting on $\beta$ adrenoceptors, stimulate ZG cells either directly (Horiuchi et al., 1987) or through renin secretion (Holmer et al., 1997). We reported that chronic propranolol treatment decreased the volume of the $Z G$ and the total number of parenchymal cells in it (Plećaš et al., 1996). It seems that in the presence of EDS the ZG cells lose their ability to respond to $b$ adrenoceptor stimulation by significant morphological alteration. This finding may also indicate that different mechanisms are involved in the regulation of ZG cells by ACTH and isoproterenol when they are exposed to the toxic influence of EDS.

In rats whose adrenals were already suppressed with dexamethasone (Leœniewska et al., 1992), the effects of EDS were much more pronounced. Compared with the values measured in saline and EDS-injected controls significant reductions were found in the volume and cellularity of all cortical zones and the mean volume of the ZF cells. However, despite severe adrenal atrophy an almost $50 \%$ decrease in mean serum corticosterone concentration was not statistically significant. Most probably, the compensatory hypertrophy of the ZR cells, which in rats produce corticosterone (Almeida et al., 1998), contributed to the maintenance of the blood corticosterone level.

Before making a conclusion, it is necessary to comment on the use of ether anaesthesia when it is known that ether stress elevates blood corticosterone level (Laczi et al., 1994). To avoid this rise, blood samples were taken within 2 minutes of total anaesthesia (Villas et al., 1991). Hence, the basal concentration of serum corticosterone of untreated animals, which were kept and handled in the same way as the experimental rats, was found to be $165.28 \pm 15.51 \mathrm{ng} / \mathrm{ml}$. This concentration is in the range or even lower than some values obtained for control rat blood taken at the same time of day after decapitation (Rebuffat et al., 1989; Leœnievska et al., 1992; Pignatelli et al., 1995).

The results of the morphometric study presented in this work demonstrate that stimulators of adrenocortical function and growth, such as ACTH or $\beta$ adrenoceptor activation, protect rat adrenal cortex from the toxic effects of EDS, while dexamethasone, as a powerful inhibitor, potentiated those effects. 
Address for correspondence:

Prof. Dr Bosiljka Plećaš-Solarović

Faculty of pharmacy

University of Belgrade

11000 Belgrade, Serbia \& Montenegro

\section{REFERENCES}

1. Almeida H, Magalhães MC, Magalhães MM, 1998, Age-related changes in the inner zone of the adrenal cortex of the rat - a morphologic and biochemical study, Mech Ageing Dev, 105, 1-18.

2. Berkenbosch F, Vermes I, Binnekade R, Tilders FJH, 1981, Beta-adrenergic stimulation induces an increase of the plasma levels of immunoreactive $\alpha-\mathrm{MSH}, \beta$-endorphin, ACTH and corticosterone, Life Sci, 29, 2249-56.

3. Carlisle HJ, Frost TS, Stock MJ, 1999, Thermal preference behavior following clonidine, norepinephrine, isoproterenol, and ephedrine, Physiol Behav, 66, 585-9.

4. Dong Q, Handelsman DJ, 1991, Effects of ethane dimethane sulphonate and orchidectomy on luteinizing hormone secretion, $J$ Neuroendocrinol, 3, 449-53.

5. Ehling UH, Neuhäuser-Klaus A, 1995, Induction of specific-locus and dominant lethal mutations in male mice by n-propyl and isopropyl methanesulfonate, Mutat Res, 328, 73-82.

6. Erhart-Bornstein M, Hinson JP, Bornstein SR, Scherbaum WA, Vinson GP, 1998, Intraadrenal interactions in the regulation of adrenocortical steroidogenesis, Endocr Rev, 19, 101-43.

7. Holmer SR, Kaissling B, Putnik K, Pfeifer M, Krämer K, Riegger GAJ, Kurtz A, 1997, Beta-adrenergic stimulation of renin expression in vivo, $J$ Hyperertens, 15, 1471-9.

8. Horiuchi T, Tanaka K, Shimizu N, 1987, Effect of catecholamine on aldosterone release in isolated rat glomerulosa cell suspensions, Life Sci, 40, 2421-8.

9. Jackson CM, Jackson H, 1984, Comparative protective actions of gonadotrophins and testosterone against the antispermatogenic action of ethane dimethanesulphonate, J Reprod Fertil, 71, 393-401.

10. Judd AM, Spangelo BL, Mac Leod RM, 1990, Rat adrenal zona glomeruloza cells produce interleukin-6, Prog Neuro Endocrin Immunol, 3, 282-92.

11. Judd AM, Mac Leod RM, 1995, Differential release of tumor necrosis factor and IL-6 from adrenal zona glomerulosa cells in vitro, Am J Physiol, 268, E114-E120.

12. Klinefelter GR, Laskey JW, Roberts NL, 1991, In vitro/in vivo effects of ethane dimethanesulfonate on Leydig cells of adult rats, Toxicol Appl Pharmacol, 107, 460-71.

13. Klinefelter GR, Roberts NL, Suarez JD, 1992, Direct effects of ethane dimethanesulfonate on epididymal function in adult rats - an in vitro demonstration, J Androl, 13, 409-21.

14. Laczi F, Iványi T, Sarnyai Z, Vecsernyés M, Lengyel G, Szabó G et al., 1994, The role of central coticoliberin in the ether stress-induced secretion of neurohypophyseal hormones and corticosterone in the rat, Neuropeptides, 26, 33-7.

15. Leeming G, Lendon RG, McLean JM, Morris ID, 1991, Changes in the rat lymphoid tissues after Leydig cell destruction by ethane-1,2-dimethanesulphonate, Exp Pathol, 41,115-20.

16. Leœniewska B, Nowak KW, Malendowicz LK, 1992, Dexamethasone-induced adrenal cortex atrophy and recovery of the gland from partial, steroid-induced atrophy, Exp Clin Endocrinol, 100, 133-9.

17. Maisel AS, Fowler P, Rearden A, Motulsky HJ, Michel MC, 1989, A new method for isolation of human lymphocyte subsets reveals differential regulation of $b$-adrenergic receptors by terbutaline treatment, Clin Pharmacol Ther, 46, 429-39.

18. Malendowicz LK, 1987, Sex differences in adrenocortical structure and function XXIV. Comparative morphometric studies on adrenal cortex of intact male and female rats of different strains, Cell Tissue Res, 249, 443-9.

19. Mohamed-Ali V, Flower L, Sethi J, Hotamisligil G, Gray R, Humphries SE, York DA, Pinkney J, 2001, b-Adrenergic regulation of IL-6 release from adipose tissue: In vivo and in vitro studies, $J$ Clin Endocr Metab, 86, 5864-69. 
Acta Veterinaria (Beograd), Vol. 53. No. 5-6, 333-342, 2003.

Plećaš-Solarović Bosiljka et al. The effects of ACTH, isoproterenol and dexamethasone on

the rat adrenal gland response to ethane dimethanesulphonate (EDS): a stereological study

20. Morris ID, Lendon RG, Waters C, Naylor G, Jones N, 1997, Thymic regression and apoptosis in the rat after treatment with the Leydig cell cytotoxin ethylene dimethanesulphonate (EDS), Toxicol, 120, 19-27.

21. Nussdorfer GG, 1996, Paracrine control of adrenal cortical function by medullary chromaffin cell, Pharmacol Rev, 48, 495-530.

22. Pignatelli D, Pinto P, Almeida H, Magalhães MM, Magalhães MC, Ho MM Et al., 1995, The development of the adrenal cortex in the rat. An immunohistochemical study, Endocr Res, 21, 129-36.

23. Plećaš B, Hristić $M$, Jovović $D$, Popović A, 1990, The response of adrenal zona fasciculata and zona reticularis to oxytocin treatment, Exp Clin Endocrinol, 95, 192-6.

24. Plećaš B, Glavaški A, Đuric D, Hristić M, Solarović T, 1996, Stereologic study on the effects of oxytocin and propranolol on the rat adrenal cortex. Iugoslav, Physiol Pharmacol Acta, 32, 223-8.

25. Plećaš B, Glavaški A, Savić V, Hristić M, Đuric D, Solarović T, 1997, Effects of ethane dimethanesulfonate on the structure of adult male rat adrenal cortex, Pharmacol Res, 35, 541-6.

26. Plećaš B, Pešić V, Mirković D, Hristić M, Solarović T, 1999, Stimulatory effect of chronic isoproterenol administration on corticosterone secretion in intact and ethane dimethanesulphonateinjected rats, Arch Toxicol Kinet Xenobiot Metab, 7, 127-32.

27. Plećaš B, Pešić V, Mirković D, Majkić-Singh N, Hristić M, Solarović T, 2001, Opposite effects of dexamethasone and ACTH on the adrenal cortex response to ethane dimethanesulphonate (EDS), Exp Toxic Pathol, 53, 31-4.

28. Rebuffat P, Cavallini L, Belloni AS, Mazzocchi G, Coi A, de Tos GP et al., 1989, A morphometric study on the reversal of ACTH-induced hypertrophy of rat adrenocortical cells after cessation of treatment, J Submicrosc Cytol Pathol, 21, 73-81.

29. Ribelin WE, 1984, The effects of drugs and chemicals upon the structure of the adrenal gland, Fund Appl Toxicol, 4, 105-19.

30. Salas MA, Evans SW, Levell MJ, Whicher JT, 1990, Interleukin-6 and ACTH act synergistically to stimulate the release of corticosterone from adrenal gland cells, Clin Exp Immunol, 79, 470-3.

31. Sato M, Kubota Y, Malbon CC, Tohyama M, 1989, Immunohistochemical evidence that most rat corticotrophs contain $\beta$-adrenergic receptors, Neuroendocrinol, 50, 577-83.

32. Shealy YF, Krauth CA, 1993, Synthesis and antineoplastic evaluation of alpha-substituted alkanesulfonates: analogues of clomesone, J Pharm Sci, 82, 1200-4.

33. Shima S, Komoriyama K, Hirai M, Kouyama H, 1984, Studies on cyclic nucleotides in the adrenal gland, XI. Adrenergic regulation of adenylate cyclase activity in the adrenal cortex, Endocrinol, 114, 325-9.

34. Sprando LR, Santulli R, Awoniyi CA, Ewing LL, Zirkin BR,1990, Does ethane 1,2-dimethanesulphonate (EDS) have a direct cytotoxic effect on the seminiferous epithelium of the rat testis? $J$ Androl, 11, 344-52.

35. Tilders FJH, Berkenbosch F, Smelik PG, 1982, Adrenergic mechanisms involved in the control of pituitary-adrenal activity in the rat: $A \beta$-adrenergic stimulatory mechanism, Endocrinol,110, 114 20.

36. Villas PA, Dronsfield MJ, Blankenhorn EP, 1991, Experimental allergic encephalomyelitis and corticosterone studies in resistant and susceptible rat strains, Clin Immunol Immunopathol, 61, 2940.

37. Weibel ER, 1979, Stereological Methods. Practical Methods for Biological Morphometry. Vol. 1, London: Academic Press, 1-415. 


\title{
UTICAJ ACTH, IZOPROTERENOLA I DEKSAMETAZONA NA ODGOVOR NADBUBREŽNE ŽLEZDE PACOVA NA ETANDIMETANSULFONAT (EDS): STEREOLOŠKO ISPITIVANJE
}

\author{
PLEĆAŠ-SOLAROVIĆ BOSILJKA, PEŠIĆ VESNA, MIRKOVIĆ D i LEPOSAVIĆ GORDANA
}

\section{SADRŽAJ}

Alkilirajući agens etandimetansulfonat (EDS), pored toksičnog delovanja na Lajdigove ćelije semenika, izaziva izraženu atrofiju kore nadbubrežne žlezde odraslih pacova. U ovom radu je ispitivan uticaj devetodnevnog tretmana sa ACTH $(40 \mathrm{IU} / \mathrm{kg} / \mathrm{d})$, izoproterenolom $(120 \mu \mathrm{g} / \mathrm{kg} / \mathrm{d})$ ili deksametazonom $(0.25$ $\mathrm{mg} / \mathrm{kg} / \mathrm{d}$ ) na morfološke promene kore nadbubrega koje izaziva jedna intraperitonealna injekcija EDS (75 mg/kg). Tretmani su započeli 4 dana pre davanja EDS i nastavljeni su još 5 dana, a životinje su žrtvovane 15 dana posle aplikacije EDS. U prisustvu ACTH ili izoproterenola ne ispoljavaju se promene u stereološkim parametrima kore nadbubrega koje izaziva EDS. Oba tretmana značajno povećavaju i koncentraciju kortikosterona u serumu. Deksametazon, međutim, pojačava toksične efekte EDS; zapremina svih zona kore i broj parenhimskih ćelija u zonama su smanjeni, ali preostale ćelije retikularne zone pokazuju značajnu hipertrofiju, koja je verovatno odgovorna za održavanje sekrecije kortikosterona kod ovih životinja. Rezultati rada pokazuju da se toksični efekti EDS na koru nadbubrega mogu sprečiti visokim nivoom ACTH ili stimulacijom $\beta$ adrenalinskih receptora, a potencirati egzogenim glukokortikoidom. 